\title{
Simultaneous aluminum, silicon, and sodium coordination changes in 6 GPa sodium aluminosilicate glasses
}

\author{
Kimberly E. Kelsey, ${ }^{1, *}$ Jonathan F. Stebbins, ${ }^{1}$ Jed L. Mosenfelder, ${ }^{2}$ And PaUl D. Asimow ${ }^{2}$
}

\begin{abstract}
${ }^{1}$ Department of Geological and Environmental Sciences, Stanford University, Stanford, California 94305-2115, U.S.A. ${ }^{2}$ Division of Geological and Planetary Sciences, California Institute of Technology, Pasadena, California 91125, U.S.A.
\end{abstract}

\begin{abstract}
We present the first direct observation of high-coordinated $\mathrm{Si}$ and $\mathrm{Al}$ occurring together in a series of high-pressure sodium aluminosilicate glasses, quenched from melts at $6 \mathrm{GPa}$. Using ${ }^{29} \mathrm{Si}$ MAS NMR, we observe that a small amount of $\mathrm{Al}$ does not have a significant effect on the amount of ${ }^{\mathrm{V}} \mathrm{Si}$ or ${ }^{\mathrm{V}} \mathrm{Si}$ generated, but that larger $\mathrm{Al}$ concentrations lead to a gradual decrease in both these species. ${ }^{27} \mathrm{Al}$ MAS NMR spectra show that samples with small amounts of Al have extremely high mean Al coordination values of up to 5.49, but that larger $\mathrm{Al}$ concentrations cause a gradual decrease in both ${ }^{\mathrm{V}} \mathrm{Al}$ and ${ }^{\mathrm{VI}} \mathrm{Al}$. Although mean $\mathrm{Al}$ and $\mathrm{Si}$ coordination numbers both decrease with increasing Al contents, the weighted combined $(\mathrm{Al}+\mathrm{Si})$ coordination number increases. Silicon and $\mathrm{Al}$ resonances shift in frequency with increasing pressure or changing $\mathrm{Al}$ concentration, indicating additional structural changes, including compression of network bond angles. Increases in the ${ }^{23} \mathrm{Na}$ isotropic chemical shifts indicate decreases in the mean $\mathrm{Na}-\mathrm{O}$ bond lengths with increasing pressure, which are more dramatic at higher $\mathrm{Al}$ contents. Recovered glass densities are about 10 to $15 \%$ greater than those of similar ambient pressure samples. However, the density increases due to the combined coordination changes of Al and Si are estimated to total only about 1 to $2 \%$, and are roughly constant with composition despite the large effects of $\mathrm{Al}$ content on the individual coordinations of the two cations. Thus, effects of other structural changes must be significant to the overall densification. Apparent equilibrium constants for reactions involving the generation of high-coordinated species show systematic behavior, which suggests an internal consistency to the observed $\mathrm{Si}$ and $\mathrm{Al}$ coordination number shifts.
\end{abstract}

Keywords: NMR, aluminosilicate, glass, high pressure, coordination, aluminum, silicon, sodium

\section{INTRODUCTION}

As melts are subjected to increasing pressure, the local structural environment around each cation and anion undergoes changes, which can include decreases in bond angles and distances and/or increases in coordination numbers. These structural changes control the macroscopic properties of a melt, including viscosity, density, and diffusivity, which in turn affect thermodynamic and transport processes in the Earth (Kushiro 1976; Stolper et al. 1981; Rigden et al. 1984; Scarfe et al. 1987; Xue et al. 1994; Wolf and McMillan 1995; Kushiro and Mysen 2002; Lee 2005). Each component of a melt may respond to a pressure increase differently, and, in multi-component systems, may affect the structure and densification of all the other components. Therefore, it is important to study a range of composition to assess compositional effects upon compression mechanisms. The substitution of $\mathrm{Al}$ for $\mathrm{Si}$ is especially interesting in affecting melt density, viscosity (Toplis et al. 1997), and configurational entropy (Lee and Stebbins 1999). As it is difficult to study highpressure melts in situ, it is common instead to study glasses formed by rapid cooling of melts, which quenches the structure of that melt at the fictive temperature to a first approximation. Post-quench cooling and recovery to ambient pressure can both affect the structure, and these factors must be considered

* E-mail:kkelsey@stanford.edu before extrapolating studies of high-pressure glasses to highpressure-high-temperature systems (Wolf et al. 1990; Wolf and McMillan 1995; Farber and Williams 1996; Mysen et al. 2005; Allwardt et al. 2005a, 2005b; Dubinsky et al. 2006; Stebbins et al. 2008).

As a melt is compressed, network-forming cations (including $\mathrm{Si}$ and $\mathrm{Al}$ ) commonly respond with an increase in coordination number. High-coordinated Si has been previously reported in high-pressure silicate glasses (Xue et al. 1989, 1991; Stebbins and Poe 1999; Allwardt et al. 2004), and high-coordinated Al has been observed using various techniques in aluminosilicate glasses (Wolf and McMillan 1995; Yarger et al. 1995; Li et al. 1995; Poe et al. 2001; Lee et al. 2006; Allwardt et al. 2005a, 2005b; Kelsey et al. 2009). However, in aluminosilicate glasses the Al apparently changes coordination more readily than does the $\mathrm{Si}$ and, to date, high-coordinated $\mathrm{Si}$ has not been directly observed in high-pressure aluminosilicate glasses (Yarger et al. 1995; Allwardt et al. 2007; Kelsey et al. 2009), although it has been inferred from ${ }^{17} \mathrm{O} 3$ QMAS NMR (Lee 2004). It has been hypothesized that if both $\mathrm{Al}$ and $\mathrm{Si}$ are present in a glass, the $\mathrm{Al}$ will change coordination number instead of the $\mathrm{Si}$ because $\mathrm{Al}$ is better charge balanced with 5 or 6 oxygen ions than is $\mathrm{Si}$ and has a slightly larger cation radius. In aluminosilicate glasses, it appears that the dominant, recovered structural change around the $\mathrm{Si}$ cations involves the decrease in $\mathrm{Si}-\mathrm{O}-(\mathrm{Si}, \mathrm{Al})$ bond angles 
instead of an increase in coordination. Composition strongly influences the amount of high-coordinated Al and Si generated: variations in both $\mathrm{NBO} / \mathrm{T}$ ratios and in the field strength of the modifier cations are known to be especially important (Xue et al. 1991; Allwardt et al. 2005b; Kelsey et al. 2009).

Structural changes in network modifier environments with pressure are also known, and must be related to changes in the network. Sodium aluminosilicate glasses are especially useful experimental systems for studying these changes, as high-resolution NMR can characterize the short-range structure around all of the cations (as well as the oxygen anions), thus providing a more complete understanding of the interactions and trade-offs among different pressure effects. Large, low-charged networkmodifying/charge-balancing cations such as $\mathrm{Na}^{+}$commonly respond to pressure increases through a decrease in average bond lengths as the cation site is compressed (Allwardt et al. 2005b, 2005c; Lee et al. 2006; Kelsey et al. 2009).

Much is known about compositional effects on the structure of sodium aluminosilicate glasses that has bearing on the compositions studied here. For example, previous studies of ambient-pressure sodium aluminosilicate glasses have suggested that Al-Si substitution can take place in two structural units with different inter-tetrahedral angles, whose concentrations depend on Al content (Neuville and Mysen 1996); that Al-Si ordering increases with increasing Al content (Toplis et al. 1997); and that aluminum avoidance (i.e., the absence of Al-O-Al clusters) is nearly complete but does vary with Al content (Lee and Stebbins 1999). Mysen et al. (2003), in a study of glasses along the $\mathrm{Na}_{2} \mathrm{Si}_{3} \mathrm{O}_{7}-\mathrm{Na}_{2}(\mathrm{NaAl})_{3} \mathrm{O}_{7}$ join, observed an increase in the frequency of the ${ }^{29} \mathrm{Si}$ NMR peak maximum with increasing $\mathrm{Al}$ content and determined that the $\mathrm{Al}$ is dominantly located in $\mathrm{Q}^{4}$ structural units. Lee and Stebbins (2003) used ${ }^{23} \mathrm{Na} \mathrm{NMR}$ to conclude that substituting charge-balanced $\left(\mathrm{NaAlO}_{2}\right)$ for $\mathrm{SiO}_{2}$ causes a decrease in average $\mathrm{Na}-\mathrm{O}$ bond distances on the $\mathrm{SiO}_{2}-\mathrm{NaAlO}_{2}$ join.

Several studies of alkali silicate and aluminosilicate glasses have also described structural changes in densified glasses quenched from melts at high pressure and returned to ambient conditions, the approach followed here. As sodium silicate glasses densify, ${ }^{\mathrm{V} V I} \mathrm{Si}$ forms and is most abundant in the $\mathrm{Na}_{2} \mathrm{Si}_{4} \mathrm{O}_{9}$ composition (Xue et al. 1989, 1991). It appears that these high-coordinated species are initially generated at the expense of non-bridging oxygen (NBO), but may involve bridging $\mathrm{O}$ atoms (BO) as well at higher pressures (Wolf et al. 1990), as has also been reported for high-pressure potassium silicate glasses (Allwardt et al. 2004). Furthermore, in high-pressure sodium silicates, changes in the ${ }^{\mathrm{IV}} \mathrm{Si}$ NMR line shape have been attributed to increased $\mathrm{Q}$ species disproportion as $\mathrm{Q}^{3}$ are converted to $\mathrm{Q}^{2}$ and $\mathrm{Q}^{4}$ species, along with a decrease in the mean Si-O-Si angle and the development of Si-O- ${ }^{\mathrm{V}, \mathrm{VI}} \mathrm{Si}$ (Xue et al. 1989, 1991). In $\mathrm{Na}_{2} \mathrm{Si}_{4} \mathrm{O}_{9}$ glasses, ${ }^{23} \mathrm{Na} \mathrm{NMR}$ suggested a very slight increase in $\mathrm{Na}-\mathrm{O}$ distances with increasing pressure (Lee et al. 2006). In sodium aluminosilicate glasses, significant amounts of highcoordinated Al have been observed. However, this appears to be at the expense of the highly coordinated $\mathrm{Si}$, as no ${ }^{\mathrm{V}, \mathrm{VI}} \mathrm{Si}$ has been directly detected, although it has been suspected from ${ }^{17} \mathrm{O}$ NMR (Lee 2004). As for the Al-free compositions, increasing pressure also causes a decrease in NBO, indicating that this may be involved in the generation of high-coordinated aluminum (Lee 2004; Lee et al. 2004). This effect has been reported for potassium and calcium aluminosilicate glasses (Allwardt et al. 2005c). There also appears to be a decrease in Na-O distances in densified sodium aluminosilicate glasses (Yarger et al. 1995; Allwardt et al. 2005b; Lee et al. 2006).

In this study, we use ${ }^{29} \mathrm{Si},{ }^{27} \mathrm{Al}$, and ${ }^{23} \mathrm{Na} \mathrm{NMR}$ to examine sodium aluminosilicate glasses quenched from melts at ambient pressure and at $6 \mathrm{GPa}$, with compositions (Fig. 1) based on adding $\mathrm{Na}_{2} \mathrm{Al}_{2} \mathrm{O}_{4}$ to $\mathrm{Na}_{2} \mathrm{Si}_{3} \mathrm{O}_{7}$ (NS3 series) and to $\mathrm{Na}_{2} \mathrm{Si}_{4} \mathrm{O}_{9}$ (NS4 series). Given the likelihood that most NBO are associated with $\mathrm{Si}$, not $\mathrm{Al}$, the nominal (low pressure) ratio of $\mathrm{NBO} / \mathrm{Si}$ should remain roughly constant along each of these joins, simplifying interpretations of spectra. The range of $\mathrm{Al}$ contents was chosen such that, at its low end, even the extreme case of transformation of all $\mathrm{Al}$ to ${ }^{\mathrm{VI}} \mathrm{Al}$ would allow some increase in $\mathrm{Si}$ coordination if the mean $\mathrm{Si}+\mathrm{Al}$ coordination were similar to that reported in Al-free glasses. At the high end of the range, this same mean coordination change could be accommodated entirely by Al.

\section{MATERIALS AND METHODS}

\section{Sample synthesis}

All starting glasses (Table 1) were formed from mixtures of $\mathrm{Na}_{2} \mathrm{CO}_{3}, \mathrm{Al}_{2} \mathrm{O}_{3}$, and $\mathrm{SiO}_{2}\left(95 \%{ }^{29} \mathrm{Si}\right.$ for some samples), with $0.15 \mathrm{wt} \% \mathrm{Co}_{3} \mathrm{O}_{4}$ added to speed spinlattice relaxation rates. These mixtures were melted in air for $45 \mathrm{~min}$ in crimped platinum tubes (to minimize $\mathrm{Na}$ loss) in batches of $0.5-2 \mathrm{~g}$ at ambient pressure and $1300{ }^{\circ} \mathrm{C}$ and quenched by dipping the tubes in water. To ensure compositional homogeneity and full dissolution of $\mathrm{Al}_{2} \mathrm{O}_{3}$, some of the glasses were reground and re-melted for $30 \mathrm{~min}$. Starting glasses were then melted at $1620-1720^{\circ} \mathrm{C}$ and 6 GPa in a Walker-style multi-anvil device (Table 1). Glass powders were placed in welded Pt capsules with outer diameters of $4 \mathrm{~mm}$ and lengths of $3.0-4.0 \mathrm{~mm}$ and run in 25/15 type injection-molded $\mathrm{MgO}+$ spinel assemblies with $\mathrm{LaCrO}_{3}$ heaters The press calibration was performed at $1200^{\circ} \mathrm{C}$ and extrapolated up to $1600{ }^{\circ} \mathrm{C}$. We estimate the pressure uncertainty to be $\pm 0.5 \mathrm{GPa}$. For all runs, the samples were first compressed to the desired pressure, and then heated at $300-500^{\circ}$ per min to the desired temperature, which was maintained for about $5 \mathrm{~min}$ before the samples were quenched by turning off the furnace. Given what is known about melt viscosity, structural relaxation times in all of these compositions at temperatures above their liquidi should be much shorter than the run times (Webb and Dingwell 1995). The temperature was controlled using a $\mathrm{W}_{5} \mathrm{Re}-\mathrm{W}_{26} \mathrm{Re}$ thermocouple separated

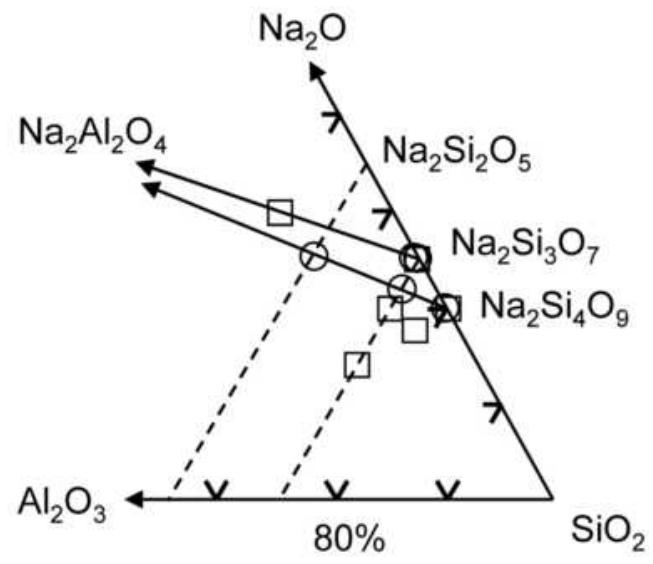

Figure 1. A portion of the $\mathrm{Na}_{2} \mathrm{O}-\mathrm{Al}_{2} \mathrm{O}_{3}-\mathrm{SiO}_{2}$ ternary diagram showing the high-pressure glasses described here (circles) and in previous studies (squares) from Yarger et al. (1995), Allwardt et al. (2005a), and Xue et al. $(1989,1991)$. The dashed lines are drawn at 75 and $66.67 \%$ $\mathrm{SiO}_{2}$. Central arrows show vectors for increasing $\mathrm{Na}_{2} \mathrm{Al}_{2} \mathrm{O}_{4}$ content. 
TABLE 1. Nominal compositions (mol\%) and synthesis conditions of glass samples

\begin{tabular}{lccccc}
\hline $\mathrm{Al} /(\mathrm{Al}+\mathrm{Si})$ & $\mathrm{Al}_{2} \mathrm{O}_{3} \pm 0.2 \%$ & $\mathrm{SiO}_{2} \pm 1 \%$ & $\mathrm{Na}_{2} \mathrm{O} \pm 1 \%$ & $P$ & $T\left({ }^{\circ} \mathrm{C}\right)$ \\
\hline NS3 series & 0.0 & 75.0 & 25.0 & $1 \mathrm{~atm}$ & 1300 \\
0.0 & 0.0 & 75.0 & 25.0 & $6 \mathrm{GPa}$ & 1720 \\
0.0 & 0.5 & 74.0 & 25.5 & $1 \mathrm{~atm}$ & 1300 \\
0.013 & 0.5 & 74.0 & 25.5 & $6 \mathrm{GPa}$ & 1715 \\
0.013 & 0.25 & 79.5 & 20.25 & $1 \mathrm{~atm}$ & 1300 \\
NS4 series & 0.25 & 79.5 & 20.25 & $6 \mathrm{GPa}$ & 1720 \\
0.006 & 0.5 & 79.1 & 20.4 & $1 \mathrm{~atm}$ & 1300 \\
0.006 & 1.0 & 78.2 & 20.8 & $1 \mathrm{~atm}$ & 1300 \\
0.012 & 3.1 & 75.0 & 21.9 & $1 \mathrm{~atm}$ & 1300 \\
0.025 & 3.1 & 75.0 & 21.9 & $6 \mathrm{GPa}$ & 1620 \\
0.076 & 8.3 & 66.7 & 25.0 & $1 \mathrm{~atm}$ & 1300 \\
0.076 & 8.3 & 66.7 & 25.0 & $6 \mathrm{GPa}$ & 1648 \\
0.20 & \multicolumn{5}{c}{} \\
0.20 & Note: Estimated uncertainties are based on EPMA data. \\
\hline \multicolumn{7}{l}{} \\
\hline
\end{tabular}

from the capsule by a $0.35 \mathrm{~mm}$ thick alumina disk. Once quenched, the samples were decompressed over a period of 18-24 h. Electron microprobe analyses were obtained on 5-15 random spots on at least three separate fragments of each sample, at $15 \mathrm{kV}$ with a sample current of $17 \mathrm{nA}$ and a $10 \mu \mathrm{m}$ spot size. At each point, $\mathrm{Na}$ was analyzed first, with a mean atomic number background correction procedure that eliminated off-peak background data collection (Donovan and Tingle 1996), and a $20 \mathrm{~s}$ counting time, all of which minimized Na migration away from the electron beam. All samples had the desired composition within uncertainties (standard deviation for each oxide component was less than $1 \%$ absolute), with no evidence of heterogeneity. No crystals were detected using optical microscopy, ${ }^{29} \mathrm{Si} \mathrm{NMR}$, or ${ }^{27} \mathrm{Al}$ NMR in any of the glass samples except for the NS4 glass with $\mathrm{Al} /(\mathrm{Al}+\mathrm{Si})=0.20$, which contained a small amount $(\sim 3 \%)$ of crystalline jadeite detectable in both the ${ }^{29} \mathrm{Si}$ NMR and ${ }^{27} \mathrm{Al}$ NMR spectra. Microprobe analysis indicated that the glassy portion of this sample maintained the nominal contents of $\mathrm{Al}_{2} \mathrm{O}_{3}, \mathrm{SiO}_{2}$, and $\mathrm{Na}_{2} \mathrm{O}$.

\section{NMR data collection}

The ${ }^{27} \mathrm{Al}$ and ${ }^{23} \mathrm{Na}$ MAS spectra were collected using Varian/Chemagnetics "T3" probes on Varian Unity/INOVA spectrometers at $18.8 \mathrm{~T}(208.4$ and $211.6 \mathrm{MHz}$, respectively) and $14.1 \mathrm{~T}$ (156.3 and $158.7 \mathrm{MHz}$, respectively). The ${ }^{29} \mathrm{Si}$ MAS NMR spectra were collected using a Varian/Chemagnetics 3.2 "T3" probe on a Varian Infinity spectrometer at $9.4 \mathrm{~T}(79.4 \mathrm{MHz})$. Samples were spun at $12-22 \mathrm{kHz}$ in 3.2 $\mathrm{mm} \mathrm{ZrO} 2$ rotors. The ${ }^{27} \mathrm{Al},{ }^{29} \mathrm{Si}$, and ${ }^{23} \mathrm{Na}$ chemical shifts are reported relative to 0.1 $M$ aqueous $\mathrm{Al}\left(\mathrm{NO}_{3}\right)_{3}$, tetramethylsilane, and $1 M$ aqueous $\mathrm{NaCl}$, respectively. The MAS experiments used single pulse acquisition with a pulse width corresponding to a solid radiofrequency (rf) tip angle of $\sim 30^{\circ}$ (about $0.2 \mu \mathrm{s}$ for ${ }^{27} \mathrm{Al}, 0.7 \mu \mathrm{s}$ for ${ }^{29} \mathrm{Si}$, and $0.4 \mu \mathrm{s}$ for ${ }^{23} \mathrm{Na}$ ). Signal-to-noise was optimized by collecting 200 to 500000 transients with pulse delays of 10 to $0.01 \mathrm{~s}$. For several of the $1 \mathrm{~atm}$ and $6 \mathrm{GPa}$ glasses, ${ }^{29} \mathrm{Si}$ spectra were collected with a range of pulse delays, and as no differential relaxation was observed it is unlikely that there is significant phase separation in the glasses (Sen and Stebbins 1994). The MAS spectra were fit using the program NUTS (Acorn NMR, Inc.) by manually adjusting the peak position, width, and intensity for Gaussian lineshapes to minimize the difference between the simulated spectra and the experimental spectra (Kelsey et al. 2009); manual adjustment was used to avoid "overfitting" of baseline imperfections by regression software; peaks are well-enough resolved so that direct integration gave similar results. For the ${ }^{27} \mathrm{Al}$ MAS NMR data, background spectra were also collected for each rotor used and were subtracted before further processing of the data. This signal, due to a trace amount of $\mathrm{Al}$ in the zirconia rotor, amounted to a maximum of about $15 \%$ of the total signal for the lowest-Al glass, and is typically insignificant at $\mathrm{Al}_{2} \mathrm{O}_{3}$ contents above a few percent.

\section{Density measurements}

Glass densities were measured using the sink/float method, in which all samples of a given series were placed in a small beaker containing a known amount of diiodomethane. Acetone was added in excess until all samples were denser than the solution. The acetone was then gradually evaporated until each sample started to float, at which point the weight of the solution was measured and used to calculate the weight of acetone and density of the solution. Once all samples were floating, additional acetone was added and the measurement was reproduced at least once. A CaMgSi ${ }_{2} \mathrm{O}_{6}$ glass standard with a density of $2.8 \mathrm{~g} / \mathrm{cm}^{3}$ was analyzed both before and after each series of glasses. For each sample, the largest portion of the glass was chosen for analysis. However, for one glass sample in each series, three separate glass shards were chosen for analysis to test for uniformity. The densities of the 1 atm samples are not reported because air bubbles caused inconsistent measurements among different fragments of the same glass. However, several literature reports of the densities of sodium silicate glasses provide useful comparisons to those of the high-pressure samples (see below).

\section{RESULTS}

\section{${ }^{29} \mathrm{Si}$ NMR}

The ${ }^{29}$ Si MAS NMR spectra for the NS3 and NS4 series of glasses synthesized at $6 \mathrm{GPa}$ are presented in Figure 2 and the coordination numbers obtained by fitting are given in Table 2 . The spectra consist of signals from up to three different Si environments, ${ }^{\mathrm{IV}} \mathrm{Si},{ }^{\mathrm{V}} \mathrm{Si}$, and ${ }^{\mathrm{VI}} \mathrm{Si}$, which have maxima located at about $-90,-150$, and $-200 \mathrm{ppm}$, respectively. The NS4 glass with Al/ $(\mathrm{Al}+\mathrm{Si})=0.20$ contains about $3 \%$ crystalline jadeite, as labeled. Based on data for pure synthetic jadeite (Kelsey et al. 2007), this signal was subtracted before the proportions of the various coordination numbers and the centers of gravity were determined. The NS3 series has lower Si coordination numbers relative to the NS4 series at similar Al contents, which is consistent with previous results suggesting that the $\mathrm{Na}_{2} \mathrm{Si}_{4} \mathrm{O}_{9}$ composition may be near a maximum with respect to $\mathrm{Si}$ coordination increases (Xue et al. 1991). In the NS3 series, the samples with and without Al have nearly identical amounts of ${ }^{\mathrm{V}} \mathrm{Si}$ and ${ }^{\mathrm{V}} \mathrm{Si}$, indicating that the presence of very small amounts of Al does not significantly affect the generation of high-coordinated Si. Similarly, the glass with $\mathrm{Al} /(\mathrm{Al}+\mathrm{Si})$ of 0.006 in the NS4 series yields results quite similar to those of previous work on an Al-free $\mathrm{Na}_{2} \mathrm{Si}_{4} \mathrm{O}_{9}$ glass synthesized at $6 \mathrm{GPa}$ (Xue et al. 1991), which contained $3.0 \%{ }^{\mathrm{v}} \mathrm{Si}$ and $2.1 \%{ }^{\mathrm{VI}} \mathrm{Si}$. When larger amounts of $\mathrm{Al}$ are added (as $\left.\mathrm{NaAlO}_{2}\right)$, there is a gradual decrease in the $\mathrm{Si}$ coordination, and there is only $0.3 \%{ }^{\mathrm{V}} \mathrm{Si}$ and less than $0.2 \%{ }^{\mathrm{VI}} \mathrm{Si}$ when $\mathrm{Al} /(\mathrm{Al}+\mathrm{Si})$ reaches $0.20{ }^{\mathrm{V}, \mathrm{VI}} \mathrm{Si}$ was not detected at the $0.2 \%$ level in any of the $1 \mathrm{~atm}$ glasses, but it is likely that tiny amounts of ${ }^{\mathrm{v}} \mathrm{Si}$ are present, as $0.045 \%$ of this species was observed in a more detailed study of 1 atm $\mathrm{Na}_{2} \mathrm{Si}_{4} \mathrm{O}_{9}$ glasses (Stebbins and McMillan 1993). As the different $\mathrm{Si}$ resonances are well resolved, the error in each of the Si coordination values reported in Table 2 is \pm 0.2 , resulting in an uncertainty in the mean Si coordination number of \pm 0.005 .

Figures 3 and 4 show the ${ }^{\text {IV }} \mathrm{Si}$ regions of the ${ }^{29} \mathrm{Si}$ MAS NMR spectra in more detail. The center of gravity for each ${ }^{\mathrm{IV}} \mathrm{Si}$ peak was also measured (Table 2). The ${ }^{\text {IV }} \mathrm{Si}$ resonance in the $1 \mathrm{~atm}$

TABLE 2. The pressure, relative proportions of Si species (\%), mean $\mathrm{Si}$ coordination numbers ( $\mathrm{CN})$, and the centers of gravity for the "Vi resonances (cg, ppm)

\begin{tabular}{lccrccc}
\hline $\mathrm{Al} /(\mathrm{Al}+\mathrm{Si})$ & $P$ & ${ }^{\mathrm{IV}} \mathrm{Si} \pm 0.2$ & ${ }^{\mathrm{V}} \mathrm{Si} \pm 0.2$ & ${ }^{\mathrm{V}} \mathrm{Si} \pm 0.2$ & $\mathrm{SiCN} \pm 0.005$ & ${ }^{\mathrm{I}} \mathrm{Si} \mathrm{cg} \pm 0.2$ \\
\hline NS3 series & & & & & & \\
0.0 & $1 \mathrm{~atm}$ & 100 & $<0.2$ & $<0.2$ & 4.0 & -94.2 \\
0.0 & $6 \mathrm{GPa}$ & 95.4 & 2.2 & 2.4 & 4.07 & -91.3 \\
0.013 & $1 \mathrm{~atm}$ & 100 & $<0.2$ & $<0.2$ & 4.0 & -93.8 \\
0.013 & $6 \mathrm{GPa}$ & 95.4 & 2.2 & 2.4 & 4.07 & -92.2 \\
NS4 series & & & & & & \\
0.006 & $1 \mathrm{~atm}$ & 100 & $<0.2$ & $<0.2$ & 4.0 & -97.2 \\
0.006 & $6 \mathrm{GPa}$ & 94.0 & 3.0 & 3.0 & 4.09 & -94.7 \\
0.076 & $1 \mathrm{~atm}$ & 100 & $<0.2$ & $<0.2$ & 4.0 & -94.7 \\
0.076 & $6 \mathrm{GPa}$ & 97.5 & 1.6 & 1.0 & 4.04 & -93.0 \\
0.20 & $1 \mathrm{~atm}$ & 100 & $<0.2$ & $<0.2$ & 4.0 & -89.5 \\
0.20 & $6 \mathrm{GPa}$ & 99.7 & 0.3 & $<0.2$ & 4.003 & -88.0 \\
\hline
\end{tabular}




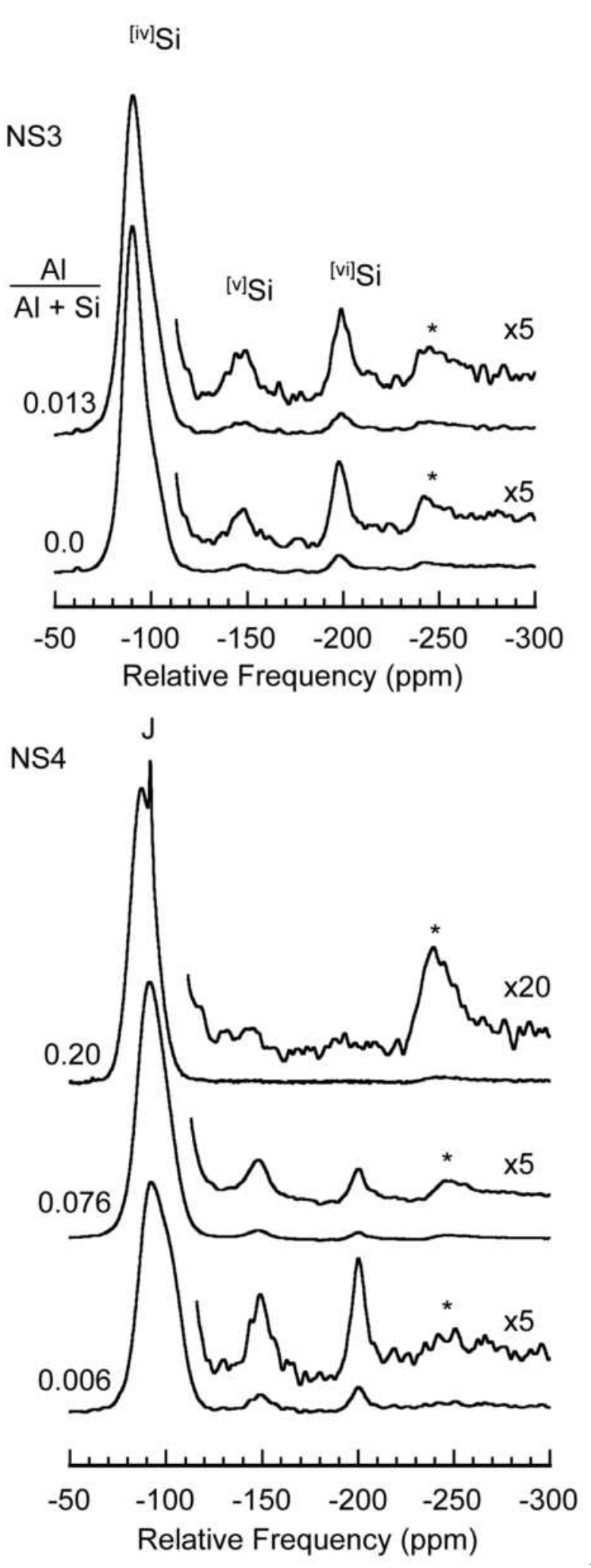

FIGURE 2. The ${ }^{29} \mathrm{Si}$ MAS NMR spectra (9.4 T) for $6 \mathrm{GPa}$ glasses in the NS3 and NS4 series with compositions as labeled. Insets show portions of spectra with vertical scales enlarged by 5 or 20 times to highlight the peaks for high-coordinated Si. Small peaks at $-250 \mathrm{ppm}$ are spinning sidebands, labeled with "**" here and in later figures. "J" indicates a crystalline jadeite impurity.

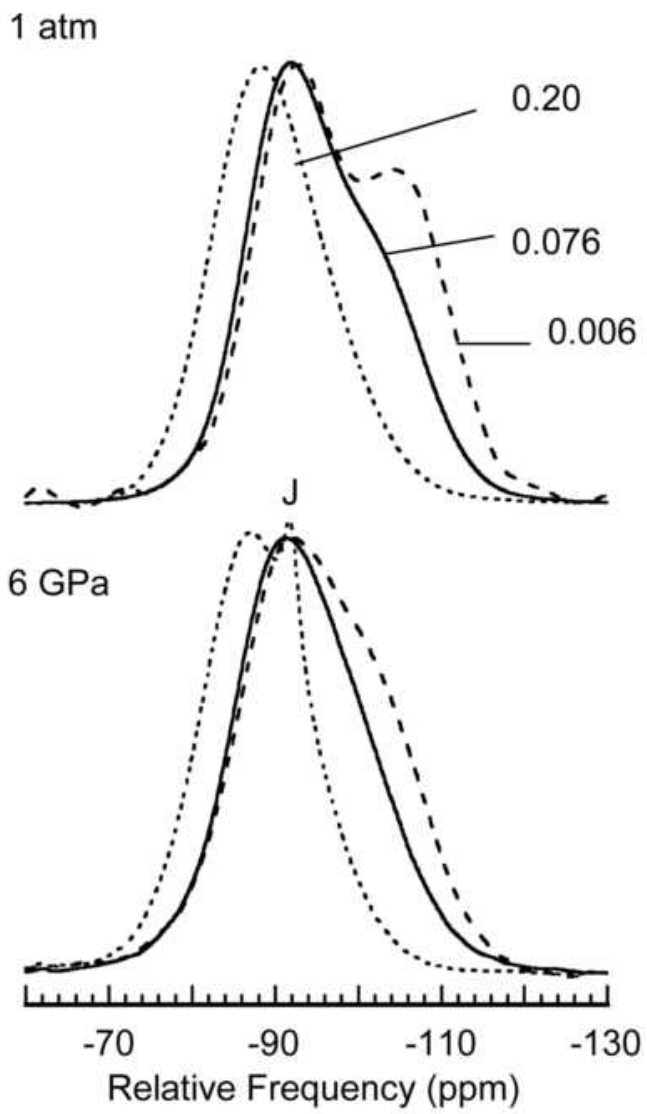

FigURE 3. The ${ }^{29} \mathrm{Si} \mathrm{MAS} \mathrm{NMR} \mathrm{spectra}(9.4 \mathrm{~T})$ for $1 \mathrm{~atm}$ and $6 \mathrm{GPa}$ glasses in the NS4 series with $\mathrm{Al} /(\mathrm{Al}+\mathrm{Si})=0.006$ (dashed), 0.076 (solid), and 0.20 (dotted). "J" indicates the jadeite impurity.

NS4 glass with the lowest Al content clearly shows two overlapping components, centered at around -93 and $-106 \mathrm{ppm}$. These are well known to be associated with the $\mathrm{Q}^{3}$ and $\mathrm{Q}^{4}$ species (Kirkpatrick 1988; MacKenzie and Smith 2002). As pressure increases, both of these peaks shift toward higher frequency, indicating a decrease in the average Si-O-Si angle, and merge together, consistent with earlier work (Xue et al. 1991). Previous observations suggested that increasing pressure favors the right-hand side of the reaction $2 \mathrm{Q}^{3}=\mathrm{Q}^{2}+\mathrm{Q}^{4}$ (Xue et al. 1989, 1991; Dickenson et al. 1990). However, in the compositions studied here the $\mathrm{Q}^{2}$ content is quite low and we expect this to have at most a minor effect. As the $\mathrm{Al}$ content increases, the ${ }^{\mathrm{IV}} \mathrm{Si}$ resonance shifts toward higher frequency as the $\mathrm{Si}$ atoms gain more $\mathrm{Al}$ neighbors. The ${ }^{\mathrm{IV}} \mathrm{Si}$ resonance in the $1 \mathrm{~atm} \mathrm{NS} 3$ glass (Fig. 4) also has partially resolved $\mathrm{Q}^{3}$ and $\mathrm{Q}^{4}$ peaks, but the latter is lower due to the reduced silica content and higher NBO/ $\mathrm{Si}$. As pressure increases, these two resonances again both shift toward higher frequency and merge together. However, as the $\mathrm{Al} /(\mathrm{Al}+\mathrm{Si})$ increases from 0 to 0.013 in the NS3 series, there is a slight decrease in the center of gravity for the ${ }^{\mathrm{IV}} \mathrm{Si}$ resonance, opposite to the trend observed in the NS4 series of glasses. Although it is possible that there is a slight increase in the NBO content with increasing $\mathrm{Al} /(\mathrm{Al}+\mathrm{Si})$, there may also be a small, undetected difference in Na content. In any case, this trend would not likely continue at higher $\mathrm{Al}$ contents, as Mysen et al. (2003) 

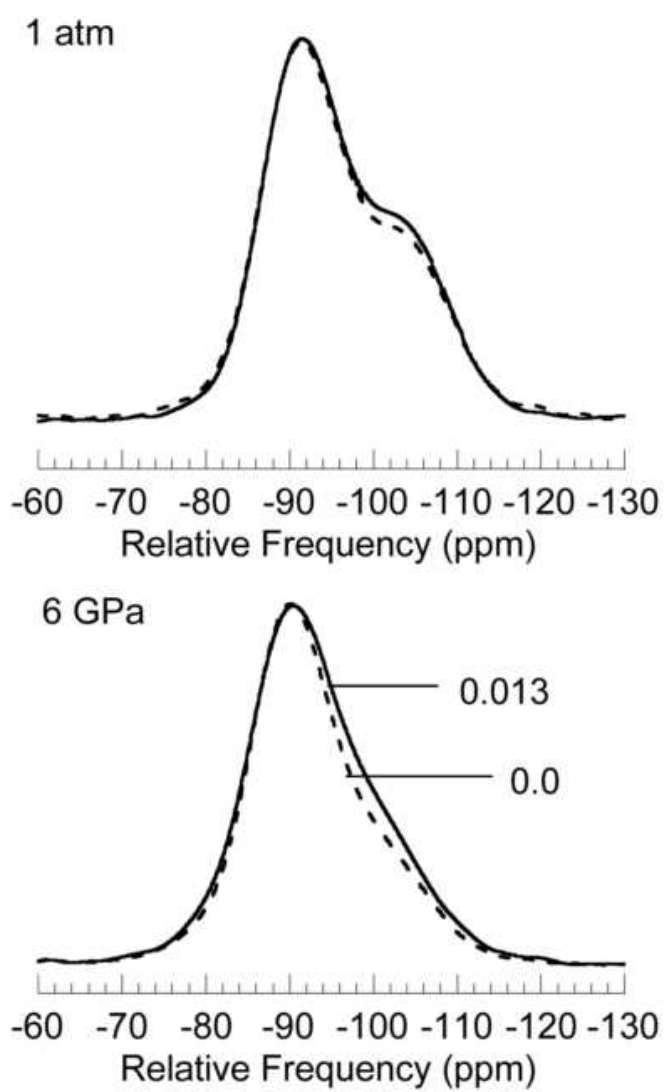

FIGURE 4. The ${ }^{29} \mathrm{Si}$ MAS NMR spectra $(9.4 \mathrm{~T})$ for $1 \mathrm{~atm}$ and $6 \mathrm{GPa}$ glasses in the NS4 series with $\mathrm{Al} /(\mathrm{Al}+\mathrm{Si})=0.0$ (dashed) and 0.013 (solid).

observed an increase in the peak maximum of the ${ }^{\mathrm{IV}} \mathrm{Si}$ resonance with increasing $\mathrm{Al}$ content in glasses similar to the NS3 series but with higher $\mathrm{Al}$ contents. The latter is also consistent with the trend observed here in the NS4 series. Because each ${ }^{\text {IV }} \mathrm{Si}$ peak is made up of contributions from $\mathrm{Q}^{2}, \mathrm{Q}^{3}$, and $\mathrm{Q}^{4}$ species with varying numbers of $\mathrm{Al}$ neighbors, we did not attempt to fit the data to quantify the speciation. There is an uncertainty of \pm 0.2 $\mathrm{ppm}$ in the centers of gravity as the ${ }^{\mathrm{IV}} \mathrm{Si}$ resonances are all fully resolved from the ${ }^{\mathrm{V}} \mathrm{Si}$ and ${ }^{\mathrm{VI}} \mathrm{Si}$.

\section{${ }^{27} \mathrm{Al}$ NMR}

The ${ }^{27} \mathrm{Al}$ MAS NMR spectra (18.8 T) for the NS3 and NS4 series of glasses synthesized at $6 \mathrm{GPa}$ and 1 atm (NS4 only) are presented in Figures 5 and 6 and the coordination numbers obtained by fitting these spectra are given in Table 3. There are three distinct resonances associated with ${ }^{\mathrm{IV}} \mathrm{Al},{ }^{\mathrm{V}} \mathrm{Al}$, and ${ }^{\mathrm{VI}} \mathrm{Al}$ located around 57, 22, and $-7 \mathrm{ppm}$, respectively. In all of the 1 atm glasses, ${ }^{\mathrm{V}} \mathrm{Al}$ is present and resolved well enough to quantify (Table 3), as is the case for both ${ }^{\mathrm{V}} \mathrm{Al}$ and ${ }^{\mathrm{VI}} \mathrm{Al}$ in the $6 \mathrm{GPa}$ glasses. However, no ${ }^{\mathrm{VI}} \mathrm{Al}$ is detected in the $1 \mathrm{~atm}$ glasses $(0.1 \%$ detection limit). Because of distributions of quadrupolar coupling constants, each resonance is slightly skewed, with a lower frequency "tail," and was thus fit with two Gaussian lineshapes, as discussed previously (Kelsey et al. 2008), to be consistent with the extensive multi-field NMR study by Neuville et al. (2006). In the NS4 sample with $\mathrm{Al} /(\mathrm{Al}+\mathrm{Si})=0.20$, a small sharp peak at -2 ppm (labeled as "J") is consistent with the presence of about 3\%
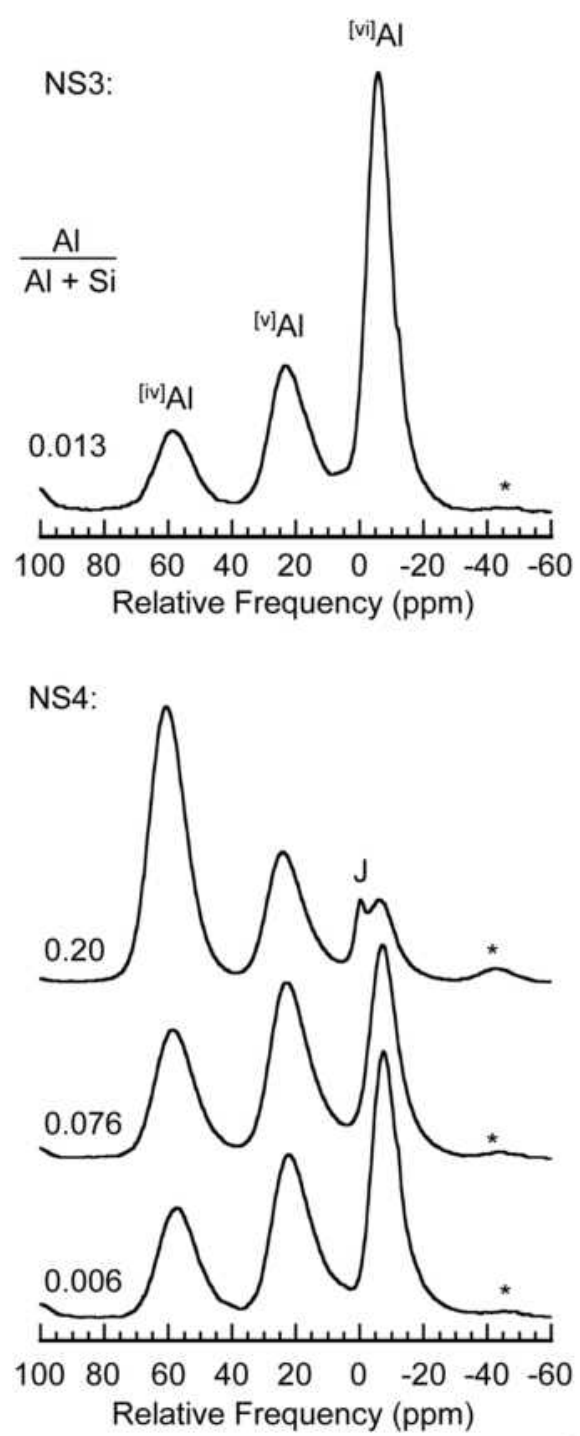

FIGURE 5. The ${ }^{27} \mathrm{Al}$ MAS NMR spectra $(18.8 \mathrm{~T})$ for $6 \mathrm{GPa}$ glasses in the NS3 and NS4 series with compositions as labeled showing the ${ }^{\mathrm{IV}} \mathrm{Al},{ }^{\mathrm{V}} \mathrm{Al}$, and ${ }^{\mathrm{VI}} \mathrm{Al}$ resonances. Small peaks at $-40 \mathrm{ppm}$ are spinning sidebands, labeled with "*” here and in later figures. "J" marks the crystalline jadeite impurity.

crystalline jadeite, as also detected in the ${ }^{29} \mathrm{Si}$ spectrum. Again based on data for pure jadeite (Kelsey et al. 2007), this signal was subtracted from the spectrum before the coordination numbers and center of gravity were determined. There is also a very small inflection in some of the spectra near $-10 \mathrm{ppm}$, which is an artifact of the rotor background subtraction. In the NS4 series, at both $1 \mathrm{~atm}$ and $6 \mathrm{GPa}$, as the $\mathrm{Al}$ content increases, there is a decrease in mean $\mathrm{Al}$ coordination, similar to the decrease for Si discussed above. The NS3 glass with $\mathrm{Al} /(\mathrm{Al}+\mathrm{Si})=0.013$ has an average $\mathrm{Al}$ coordination number of 5.49 , which is apparently higher than has been previously reported for any alumina-bearing oxide glass synthesized up to $10 \mathrm{GPa}$ (possibly excepting glasses very rich in phosphorus, Brow et al. 1993). This extreme value is clearly related to the low $\mathrm{Al}$ content, although the mean $\mathrm{Al}$ coordination of the NS4 glass with even lower Al content is somewhat less, 
indicating a complex relationship between composition and this aspect of the network structure. Because the resonances are well resolved and the spectra were fit using consistent approximations, the uncertainties in mean $\mathrm{Al}$ coordination values are about \pm 0.01 relative to data in this paper; variations in absolute estimates made with other fitting assumptions are likely to be somewhat larger, probably about \pm 0.02 .

The center of gravity for each peak is reported in Table 3. There is a slight increase in the frequency of the ${ }^{\mathrm{IV}} \mathrm{Al}$ resonance and a decrease in that for ${ }^{\mathrm{V}} \mathrm{Al}$ with increasing pressure as well as an increase in the frequencies for all of the peaks with increasing $\mathrm{Al}$ content at both $1 \mathrm{~atm}$ and $6 \mathrm{GPa}$. This shift may be due to changes in the Al-O-Si bond angles, a change in the coordination of the surrounding $\mathrm{Si}$ atoms with pressure or $\mathrm{Al}$ content, or a change in the number of second neighbor Al atoms. It is also possible that as the Al content increases there are additional AlO-Al linkages, although none of the compositions are expected to have large amounts of this species (Lee and Stebbins 1999). The asymmetry of each resonance causes some peak overlap and uncertainty in calculating the center of gravity, which we estimate as $\pm 0.3 \mathrm{ppm}$.

\section{${ }^{23}$ Na NMR}

${ }^{23} \mathrm{Na}$ MAS NMR spectra for the NS3 and NS4 glasses were collected at 18.8 and 14.1 T; the latter are shown in Figure 7. For each sample, the single resonance is slightly asymmetrical, with a minor "tail" toward lower frequency, and shifts toward higher frequency with increasing pressure. As ${ }^{23} \mathrm{Na}$ peak positions and shapes in similar samples are controlled primarily by chemical shifts and not second-order quadrupolar effects at these high fields (Lee and Stebbins 2003), this change indicates a decrease in the average $\mathrm{Na}-\mathrm{O}$ bond distance and/or coordination number with increasing pressure (Xue and Stebbins 1993). The centers of gravity were determined at both fields and were used to calculate the mean isotropic chemical shifts (Schmidt et al. 2000) (Table 4). In the NS3 series, the addition of small amounts of Al does not have a significant effect on the observed $\mathrm{Na}$ environment. However, there is a shift of just under 1 ppm toward higher frequency with increasing pressure, indicating a decrease in $\mathrm{Na}-\mathrm{O}$ bond distances of about $0.002(1) \mathrm{nm}$. In the NS4 series, there is a similar increase in mean isotropic chemical shift with increasing pressure. However, this shift increases from 0.6 to 2.1 as the $\mathrm{Al} /$ $(\mathrm{Al}+\mathrm{Si})$ increases from 0.006 to 0.20 , corresponding to decreases in Na-O bond distances of about 0.001 to $0.004 \mathrm{~nm}$. The ambient pressure glasses show only slight changes in chemical shifts with increasing $\mathrm{Al}$ content, although there seems to be a greater effect of composition in the $6 \mathrm{GPa}$ glasses. Lee et al. (2006) reported a slight decrease in the frequency of the ${ }^{23} \mathrm{Na}$ peak at $14.1 \mathrm{~T}$ with pressure in a $\mathrm{Na}_{2} \mathrm{Si}_{4} \mathrm{O}_{9}$ glass, which seems inconsistent with our results, but did describe increases in peak positions with pressure in Al-containing glasses. Our results are also consistent with those of Allwardt et al. (2005b) and Kelsey et al. (2009), who observed increases in ${ }^{23} \mathrm{Na}$ isotropic chemical shifts with increasing pressure of similar magnitude to those described here. We estimate absolute uncertainties of about $\pm 0.5 \mathrm{ppm}$ in the mean chemical shifts. However, relative values when comparing two spectra collected on similar materials under identical conditions are again probably more precise, about $\pm 0.3 \mathrm{ppm}$.

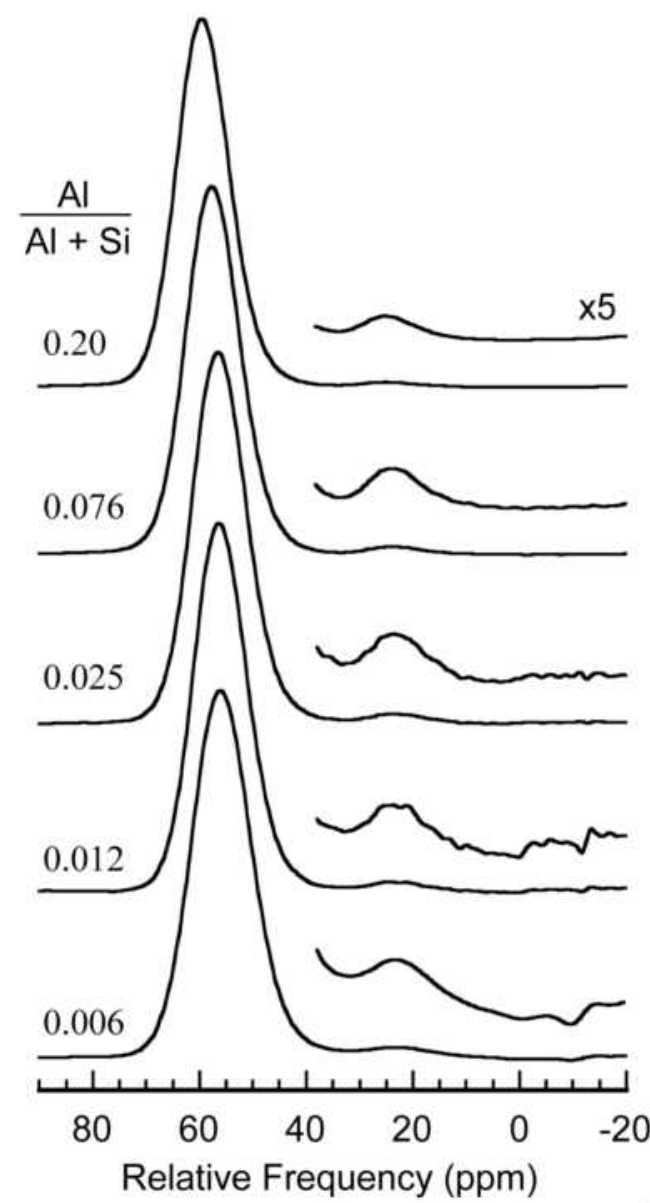

FIGURE 6. The ${ }^{27} \mathrm{Al}$ MAS NMR spectra $(18.8 \mathrm{~T})$ for $1 \mathrm{~atm}$ glasses in the NS4 series with compositions as labeled. Insets show portions of spectra with vertical scales enlarged by 5 times to better show the peaks for ${ }^{\mathrm{V}} \mathrm{Al}$.

TABLE 3. Relative proportions of Al species (\%), mean Al coordination numbers $(\mathrm{CN})$, weighted average of the $\mathrm{Si}$ and $\mathrm{Al}$ coordination numbers, and centers of gravity $(\mathrm{ppm})$ for the three $\mathrm{Al}$ resonances

\begin{tabular}{|c|c|c|c|c|c|c|c|c|c|}
\hline $\begin{array}{l}\mathrm{Al} /(\mathrm{Al} \\
+\mathrm{Si})\end{array}$ & $\bar{P}$ & $\begin{array}{l}\text { IVAl } \\
\pm 0.2\end{array}$ & $\begin{array}{l}{ }^{\mathrm{V}} \mathrm{Al} \\
\pm 0.2 \\
\end{array}$ & $\begin{array}{l}\mathrm{V}^{\mathrm{V}} \mathrm{Al} \\
\pm 0.2 \\
\end{array}$ & $\begin{array}{l}\mathrm{AlCN} \\
\pm 0.02^{*}\end{array}$ & $\begin{array}{l}(\mathrm{Al}+\mathrm{Si}) \\
\mathrm{CN} \pm 0.02 *\end{array}$ & 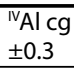 & $\begin{array}{l}{ }^{\mathrm{V}} \mathrm{Al} \mathrm{cg} \\
\pm 0.3\end{array}$ & $\begin{array}{l}\text { V'Al cg } \\
\pm 0.3\end{array}$ \\
\hline \multicolumn{10}{|c|}{ NS3 series } \\
\hline 0.013 & $1 \mathrm{~atm}$ & 98.3 & 1.7 & 0.0 & 4.017 & 4.0003 & 57.1 & 23.0 & $N / A$ \\
\hline 0.013 & $6 \mathrm{GPa}$ & 11.7 & 27.2 & 61.1 & 5.49 & 4.09 & 57.7 & 21.4 & -6.7 \\
\hline \multicolumn{10}{|c|}{ NS4 series } \\
\hline 0.006 & $1 \mathrm{~atm}$ & 97.8 & 2.2 & 0.0 & 4.022 & 4.0001 & 55.6 & 23.7 & $\mathrm{~N} / \mathrm{A}$ \\
\hline 0.006 & $6 \mathrm{GPa}$ & 21.9 & 36.9 & 41.2 & 5.19 & 4.10 & 56.2 & 20.5 & -8.5 \\
\hline 0.012 & $1 \mathrm{~atm}$ & 98.3 & 1.7 & 0.0 & 4.017 & 4.0002 & 55.9 & 24.0 & $N / A$ \\
\hline 0.025 & $1 \mathrm{~atm}$ & 98.3 & 1.7 & 0.0 & 4.017 & 4.0004 & 56.0 & 24.0 & $\mathrm{~N} / \mathrm{A}$ \\
\hline 0.076 & $1 \mathrm{~atm}$ & 98.5 & 1.5 & 0.0 & 4.015 & 4.0012 & 57.2 & 24.0 & T/A \\
\hline 0.076 & $6 \mathrm{GPa}$ & 27.0 & 39.4 & 33.6 & 5.06 & 4.11 & 57.4 & 21.2 & -7 \\
\hline 0.20 & $1 \mathrm{~atm}$ & 99.2 & 0.8 & 0.0 & 4.008 & 4.0016 & 59.1 & 25.2 & $\mathrm{~N} /$ \\
\hline 0.20 & $6 \mathrm{GPa}$ & 57.5 & 28.2 & 14.3 & 4.57 & 4.11 & 59.8 & 22.6 & -5 \\
\hline
\end{tabular}
ures) is much higher for 1 bar glasses, as these are dominated by "NAl and "Si.

\section{Glass densities}

The densities of the 6 GPa glasses are reported in Table 5. Tiny air bubbles in the 1 atm glasses prevented accurate measurements of their densities. In the table we thus include typical values from numerous literature reports of ambient pressure densities, which vary from study to study by about $\pm 0.05 \mathrm{~g} / \mathrm{cm}^{3}$. (See also several recent compilations by Doweidar 1996, 2001.) All of 


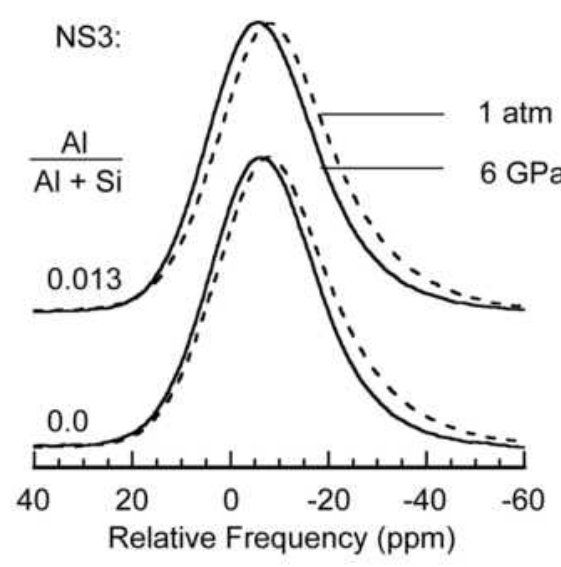

NS4:

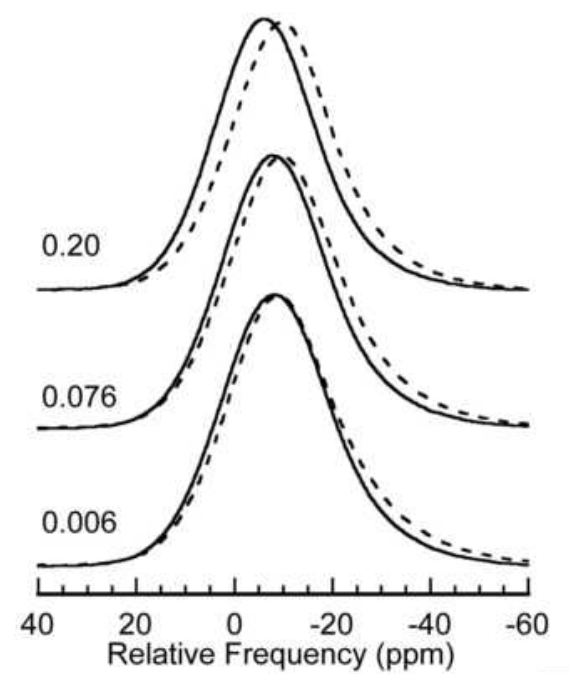

FIGURE 7. The ${ }^{23} \mathrm{Na}$ MAS NMR spectra (14.1 T) for $1 \mathrm{~atm}$ (dashed) and $6 \mathrm{GPa}$ (solid) glasses in the NS3 and NS4 series with compositions as labeled.

TABLE 4. Mean ${ }^{23} \mathrm{Na}$ isotropic chemical shifts (c.S., ppm)

\begin{tabular}{lcc}
\hline Al/(Al+Si) & $P$ & ${ }^{23} \mathrm{Na}$ c.S. \pm 0.5 \\
\hline NS3 series & $1 \mathrm{~atm}$ & \\
0.0 & $6 \mathrm{GPa}$ & 1.0 \\
0.0 & $1 \mathrm{~atm}$ & 1.8 \\
0.013 & $6 \mathrm{GPa}$ & 1.0 \\
0.013 & & 1.9 \\
NS4 series & $1 \mathrm{~atm}$ & \\
0.006 & $6 \mathrm{GPa}$ & 0.9 \\
0.006 & $1 \mathrm{~atm}$ & 1.5 \\
0.076 & $6 \mathrm{GPa}$ & 1.0 \\
0.076 & $1 \mathrm{~atm}$ & 2.2 \\
0.20 & $6 \mathrm{GPa}$ & 1.2 \\
0.20 & & 3.3 \\
\hline
\end{tabular}

the $6 \mathrm{GPa}$ glasses show density increases of $10-15 \%$ relative to $1 \mathrm{~atm}$ glasses. In the NS3 series, there is a slight increase in glass density with increasing $\mathrm{Al}$ content, which agrees with the published $1 \mathrm{~atm}$ glass densities. However, in the NS4 series, there may be a slightly more complicated trend where there is an increase in density and then a decrease. This trend is likely to be real because all samples of that series were analyzed together and we could directly observe the density of each sample relative to the others by observing the order in which they floated. Although the absolute uncertainty for the glass densities is about
TABLE 5. Measured densities for the $6 \mathrm{GPa}$ glasses and typical literature values for $1 \mathrm{~atm}$ glasses of similar compositions $\left(\mathrm{g} / \mathrm{cm}^{3}\right)$

\begin{tabular}{lcc}
\hline $\mathrm{Al} /(\mathrm{Al}+\mathrm{Si})$ & Density $(6 \mathrm{GPa}) \pm 0.02$ & Density $(1 \mathrm{~atm})$ \\
\hline NS3 series & & \\
0.0 & 2.70 & $2.43^{*}$ \\
0.013 & 2.74 & $2.43^{*}$ \\
NS4 series & & \\
0.006 & 2.75 & $2.38^{*}$ \\
0.076 & 2.79 & $2.43 \dagger$ \\
0.20 & 2.77 & $2.47 \neq$ \\
\hline * Lower et al. (2004). & & \\
† Pinnow et al. (1975). & & \\
‡ Nakashima et al. (2001). & & \\
\hline
\end{tabular}

$\pm 0.02 \mathrm{~g} / \mathrm{cm}^{3}$, smaller differences of only about $\pm 0.01 \mathrm{~g} / \mathrm{cm}^{3}$ could be detected for glasses analyzed together.

\section{DISCUSSION}

Previous NMR studies have reported Si coordination increases with pressure in alkali and calcium silicate glasses (Xue et al. 1989, 1991; Stebbins and Poe 1999; Allwardt et al. 2004). However, in aluminosilicate glasses only high-coordinated Al with all tetrahedral Si has previously been directly observed; thus it appears that $\mathrm{Al}$ increases coordination with pressure more readily than Si (Yarger et al. 1995; Allwardt et al. 2007; Kelsey et al. 2009). Our results for low-Al sodium aluminosilicate glasses are apparently the first case in which pressure-induced coordination increases for both network cations can be directly observed in the same samples. Figure 8 shows the mean $\mathrm{Al}$, $\mathrm{Si}$, and combined $(\mathrm{Al}+\mathrm{Si})$ coordination numbers as well as the densities of the high-pressure NS3 and NS4 glasses. The combined $(\mathrm{Al}+\mathrm{Si})$ coordination number is calculated by taking the weighted average of both the $\mathrm{Al}$ and $\mathrm{Si}$ coordination numbers, based on the glass composition.

In the NS3 series, the addition of a very small amount of $\mathrm{Al}$ results in an extremely large mean $\mathrm{Al}$ coordination number (5.49) without a noticeable effect on the Si coordination: the ${ }^{29} \mathrm{Si}$ MAS NMR spectra of the Al-free and Al-containing glasses are virtually identical. The high coordination of the added Al causes a slight increase in the combined $\mathrm{Al}+\mathrm{Si}$ coordination number, and is linked to a small increase in the glass density. Similarly, in the NS4 series, the distribution of Si coordination environments at $\mathrm{Al} /(\mathrm{Al}+\mathrm{Si})=0.006$ is similar to that of the $\mathrm{Al}$-free glass described by Xue et al. (1991) ( ${ }^{\mathrm{V} S i}$ of 3.0\% in both studies, ${ }^{\mathrm{VI}} \mathrm{Si}$ of $3.0 \%$ in this study and $2.1 \%$ in the previous report), even though the Al-containing glass has a mean $\mathrm{Al}$ coordination number of 5.19. The latter leads to an increase in the mean combined $(\mathrm{Al}+\mathrm{Si}$ ) coordination number of about 0.005 . As the $\mathrm{Al}$ content increases, there is a gradual decrease in both the Al and Si mean coordination numbers, and the ${ }^{\mathrm{V}, \mathrm{VI}} \mathrm{Si}$ content becomes small or undetectable when $\mathrm{Al} /(\mathrm{Al}+\mathrm{Si})$ reaches 0.20 . If this trend continues at higher $\mathrm{Al}$ contents, it would be expected that glasses of the composition described by Allwardt et al. (2005b, 2007) and Kelsey et al. (2009) would have no detectable ${ }^{\mathrm{V}, \mathrm{VI}} \mathrm{Si}$, consistent with those findings.

In both the NS3 and NS4 series, the $\mathrm{Al}$ and $\mathrm{Si}$ coordination numbers decrease with increasing Al content. However, the $(\mathrm{Al}+\mathrm{Si})$ mean coordination number increases slightly with increasing $\mathrm{Al} /(\mathrm{Al}+\mathrm{Si})$ (Table 3; Fig. 8); the density may increase slightly as well. When the two series are compared, the NS4 
has higher Si coordination numbers at similar Al contents, supporting the previous results of Xue et al. (1991) suggesting that the $\mathrm{NBO}$ concentration in $\mathrm{Na}_{2} \mathrm{Si}_{4} \mathrm{O}_{9}$ may be optimal for high-Si coordination.

As a glass or melt is compressed, the environment around a given cation may respond in different ways, including coordination number increases, decreases in bond distances and angles, or changes in the types and amounts of linkages present (e.g., $\mathrm{Si}-\mathrm{O}-\mathrm{Al}$ ). In the case of $\mathrm{Al}$ and $\mathrm{Si}$, perhaps the most obvious structural change is an increase in coordination number. However, with increasing pressure, ${ }^{29} \mathrm{Si}$ NMR spectra also show a shift toward higher frequency and a narrowing of the ${ }^{\mathrm{IV}} \mathrm{Si}$ resonance (Table 2; Figs. 3 and 4), probably indicating a decrease in the $\mathrm{Si}-\mathrm{O}-\mathrm{Si}$ and $\mathrm{Si}-\mathrm{O}-\mathrm{Al}$ bond angles. In general, this finding agrees with the conclusions from previous extensive studies of high-pressure aluminosilicate glasses by Raman spectroscopy (Mysen and Richet 2005; Poe et al. 2001). High-resolution ${ }^{17} \mathrm{O}$ NMR on high-pressure alkali silicate and alkali aluminosilicate glasses may also reveal changes in network bond angles and their distributions (Lee et al. 2003). There is as well an increase in similarity between the NMR resonances of the different $Q$ species as Na-NBO distances decrease. There must also be increases in $\mathrm{Si}-\mathrm{O}-{ }^{\mathrm{V}, \mathrm{VI}} \mathrm{Si}$ and $\mathrm{Si}-\mathrm{O}-{ }^{\mathrm{V}, \mathrm{VI}} \mathrm{Al}$ linkages with increasing pressure. For both series of glasses, the shift in frequency of the ${ }^{\text {IV }} \mathrm{Si}$ peak with pressure is larger at lower Al contents, implying that the Si tetrahedral environments experience larger changes with pressure at lower $\mathrm{Al}$ contents, along with their faster rate of conversion to high-coordinated species.

In the ${ }^{27} \mathrm{Al}$ NMR spectra, there also appear to be slight increases in the frequency of the ${ }^{\mathrm{IV}} \mathrm{Al}$ resonance in the highpressure glasses (Table 3 ). These may correspond to chemical shift changes in the same direction as that observed for ${ }^{\mathrm{IV}} \mathrm{Si}$ sites, and may thus be related to the same types of changes in bond angles and polyhedral linkages. The ${ }^{\mathrm{V}} \mathrm{Al}$ peaks seem to shift in the opposite direction, perhaps due to the development of links between high-coordinated Al sites. The ${ }^{23} \mathrm{Na}$ NMR peaks (and calculated mean isotropic chemical shifts) for all of the glasses shift to higher frequency with increasing pressure (Fig. 7), as also seen previously in sodium aluminosilicate glasses (Yarger et al. 1995; Lee et al. 2006; Kelsey et al. 2009), probably indicating a decrease in the average $\mathrm{Na}-\mathrm{O}$ bond distances of about 0.001 to $0.004 \mathrm{~nm}$, with larger changes at higher Al contents. Narrowing of network bond angles may be expected as $\mathrm{Na}^{+}$sites are compressed. All of these structural effects must eventually be linked together to try to form a more complete picture of compression mechanisms.

\section{Thermodynamic implications}

We reiterate that quenched and decompressed glasses are unlikely to provide perfectly accurate snapshots of equilibrium melt structure: some effects on glass structure have been shown to reverse on decompression (Wolf and McMillan 1995; Farber and Williams 1996), and to be better retained at decompression rates higher than those generally considered safe for the type of apparatus used here (Allwardt et al. 2005c). However, if the observed glass structures at least approximate those of the high-pressure melts at their glass transition temperatures, some thermodynamic analysis can provide a useful way of comparing
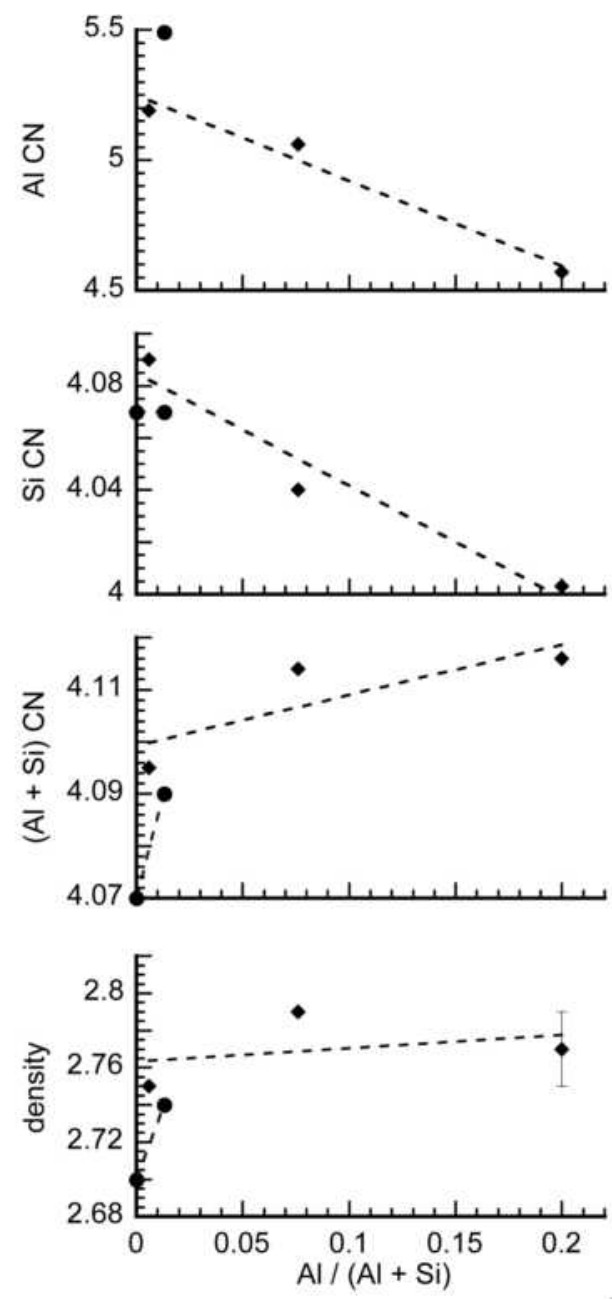

FIGURE 8. The mean $\mathrm{Al}$ coordination number, mean Si coordination number, weighted average of the $\mathrm{Al}+\mathrm{Si}$ coordination numbers $(\mathrm{Al}+\mathrm{Si})$, and glass density plotted vs. $\mathrm{Al} /(\mathrm{Al}+\mathrm{Si})$ for the NS3 (circle) and NS4 (diamond) series. Dashed best-fit lines are drawn where applicable, and serve only to indicate possible trends, not presumed linearity or for extrapolation. An uncertainty in density is shown for one composition that is typical for all points; error bars for the coordination plots are typically smaller than the symbol.

data sets and determining whether observed changes with composition are sensible. For example, a rough initial approximation of the distribution of ${ }^{\mathrm{V}} \mathrm{Si}$ and ${ }^{\mathrm{V}} \mathrm{Al}$ coordinations can be made by considering the reaction:

$$
{ }^{\mathrm{IV}} \mathrm{Si}+{ }^{\mathrm{V}} \mathrm{Al}={ }^{\mathrm{V}} \mathrm{Si}+{ }^{\mathrm{IV}} \mathrm{Al}
$$

for which an ideal, apparent equilibrium constant can be written in terms of observed mole fractions:

$$
K_{\mathrm{SA}-45} \approx\left({ }^{\mathrm{IV}} \mathrm{Si} \times{ }^{\mathrm{V}} \mathrm{Al}\right) /\left({ }^{\mathrm{V}} \mathrm{Si} \times{ }^{\mathrm{IV}} \mathrm{Al}\right) .
$$

Other reactions involving ${ }^{\mathrm{VI}} \mathrm{Si}$ and ${ }^{\mathrm{VI}} \mathrm{Al}$ could of course be written and would have apparent equilibrium constants such as:

$$
K_{\mathrm{SA}-46} \approx\left({ }^{\mathrm{IV}} \mathrm{Si} \times{ }^{\mathrm{VI}} \mathrm{Al}\right) /\left({ }^{\mathrm{VI}} \mathrm{Si} \times{ }^{\mathrm{IV}} \mathrm{Al}\right) .
$$


"Exchange" reactions written in this form may be somewhat misleading or incomplete, as they do not explicitly account for changes in the oxygen species and distribution of chargebalancing cations that must accompany network cation coordination shifts (Stebbins et al. 2008). The resulting $K$ values are not intended as quantitative predictors of speciation in other experimental systems. However, they may serve to check for consistency among data in a compositional series. Values of $\log _{10}\left(K_{\mathrm{SA}}\right)$ calculated from the data in Tables 2 and 3 are given in Table 6. All $\log _{10}\left(K_{\mathrm{SA}-45}\right)$ are within the range of $-2 \pm 0.2$, and the values for $\log _{10}\left(K_{\mathrm{SA}-46}\right)$ may be a bit lower. For the sample with $\mathrm{Al} /(\mathrm{Al}+\mathrm{Si})=0.20$, the tabulated value for $\log _{10}\left(K_{\mathrm{SA}-46}\right)$ is based on varying the (unobserved) ${ }^{\mathrm{VI}} \mathrm{Si}$ concentration from 0.05 to $0.20 \%$, which is a reasonable guess based on detection limits and trends for the other samples. For both sets of $K_{\mathrm{SA}}$, there may be some systematic effect of composition, as there appears to be a slight decrease in $\log _{10}\left(K_{\mathrm{SA}}\right)$ with increasing $\mathrm{Al}$ content in the NS4 series, but this is small with respect to uncertainties. In any case, the low values are expected from the relative ease of formation of ${ }^{\mathrm{V}} \mathrm{Al}$ compared to ${ }^{\mathrm{V}} \mathrm{Si}$.

Similarly, the distribution of $\mathrm{Al}$ among its three coordinations can be approximated by the reaction:

$$
{ }^{\mathrm{IV}} \mathrm{Al}+{ }^{\mathrm{VI}} \mathrm{Al}=2{ }^{\mathrm{v}} \mathrm{Al}
$$

with

$$
K_{\mathrm{AA}} \approx\left({ }^{\mathrm{V}} \mathrm{Al}\right)^{2} /\left({ }^{\mathrm{IV}} \mathrm{Al} \times{ }^{\mathrm{VI}} \mathrm{Al}\right) .
$$

A reaction can also be written relating the distribution of $\mathrm{Si}$ coordinations and would have:

$$
K_{\mathrm{SS}} \approx\left({ }^{\mathrm{V}} \mathrm{Si}\right)^{2} /\left({ }^{\mathrm{IV}} \mathrm{Si} \times{ }^{\mathrm{VI}} \mathrm{Si}\right) .
$$

As shown in Table $6, \log _{10}\left(K_{\mathrm{AA}}\right)$ and $\log _{10}\left(K_{\mathrm{SS}}\right)$ values are all similar, in the range of $0.1 \pm 0.1$ and $-1.6 \pm 0.1$, respectively. As with the $\log _{10}\left(K_{\mathrm{SA}-45}\right)$, the value for $\log _{10}\left(K_{\mathrm{SS}}\right)$ for the sample with $\mathrm{Al} /(\mathrm{Al}+\mathrm{Si})=0.20$ is based on ${ }^{\mathrm{V}} \mathrm{Si}$ ranging from 0.05 to 0.20 .

In a previous study, an analysis of the density increases observed for high-pressure $\mathrm{Ca}$ aluminosilicate glasses in terms of estimated partial molar volumes of ${ }^{\mathrm{IV}} \mathrm{Al}$ and ${ }^{\mathrm{V}} \mathrm{Al}$ indicated that although network cation coordination may be the most visible structural result of densification, other changes must occur that

TABLE 6. The $\log _{10}$ of apparent, ideal equilibrium constants for reactions among $\mathrm{Si}$ and $\mathrm{Al}$ species, for the $6 \mathrm{GPa}$ glasses

\begin{tabular}{lcccc}
\hline $\mathrm{Al} /(\mathrm{Al}+\mathrm{Si})$ & $\begin{array}{c}\log \left(K_{\mathrm{SA}-45}\right)^{*} \\
\pm 0.2\end{array}$ & $\begin{array}{c}\log \left(K_{\mathrm{SA}-46}\right) \dagger \\
\pm 0.2\end{array}$ & $\begin{array}{c}\log \left(K_{\mathrm{AA}}\right) \neq \\
\pm 0.1\end{array}$ & $\begin{array}{c}\log \left(K_{\mathrm{SS}}\right) \S \\
\pm 0.1\end{array}$ \\
\hline NS3 series & & & & \\
0.013 & -2.0 & -2.3 & 0.02 & -1.7 \\
NS4 series & & & & \\
0.006 & -1.7 & -1.8 & 0.18 & -1.5 \\
0.076 & -1.9 & -2.1 & 0.23 & -1.6 \\
0.20 & -2.2 & -2.7 to $-2.1 \|$ & -0.01 & -1.7 to $-2.3 \|$ \\
\hline
\end{tabular}

Note: The tabulated $K$ values are not intended as predictors of speciation in other experimental systems.

${ }^{*} K_{\mathrm{SA}-45}:{ }^{\mathrm{V}} \mathrm{Si}+{ }^{\mathrm{V}} \mathrm{Al}={ }^{\mathrm{V}} \mathrm{Si}+{ }^{\mathrm{IV}} \mathrm{Al}$.

$+K_{\mathrm{SA}-46}:{ }^{\mathrm{IV}} \mathrm{Si}+{ }^{\mathrm{VI}} \mathrm{Al}={ }^{\mathrm{VI}} \mathrm{Si}+{ }^{\mathrm{IV}} \mathrm{Al}$.

$\neq K_{\mathrm{AA}}:{ }^{\mathrm{IV}} \mathrm{Al}+{ }^{\mathrm{VI}} \mathrm{Al}=2^{\mathrm{v}} \mathrm{Al}$.

$\S K_{\mathrm{ss}}:{ }^{\mathrm{IV}} \mathrm{Si}+{ }^{\mathrm{v}} \mathrm{Si}=2^{\mathrm{v}} \mathrm{Si}$.

|| ${ }^{\mathrm{v}} \mathrm{Si}$ was below detection limits but is estimated to be in the range of 0.05 to $0.20 \%$. have similar or even greater consequences for the bulk properties (Allwardt et al. 2005b). We apply that approach here by calculating molar volumes near $T_{\mathrm{g}}$ and ambient pressure from partial molar volumes of oxide components tabulated at $1023 \mathrm{~K}$ (Lange 1997). As a crude estimate of the effects on volume of observed $\mathrm{Si}$ and $\mathrm{Al}$ coordination changes, we then approximate the partial molar volumes of ${ }^{\mathrm{V}, \mathrm{VI}} \mathrm{SiO}_{2}$ and ${ }^{\mathrm{V}, \mathrm{VI}} \mathrm{Al}_{2} \mathrm{O}_{3}$ as fixed fractions, $\mathrm{F}$, of the 1 bar values (Lange 1997). For simplicity, we consider F constant for all four high-coordinated species; extreme minimum values of F might be taken as about 0.52 (the molar volume of stishovite divided by that of the ${ }^{\mathrm{IV}} \mathrm{SiO}_{2}$ melt component) or as 0.68 (the molar volume of corundum divided by that of the ${ }^{\mathrm{IV}} \mathrm{Al}_{2} \mathrm{O}_{3}$ melt component). Using observed contents of high-coordinated $\mathrm{Al}$ and $\mathrm{Si}$, the predicted contributions to the overall volume decreases range from about $1 \%(\mathrm{~F}=0.8)$ to $2 \%(\mathrm{~F}=0.6)$. These are far less than the observed density increases of 10 to $15 \%$ (Table 5). This reinforces the conclusion that much of the densification (in these compositions and pressure range) is accommodated by compression of alkali cation sites and narrowing of network bond angles, as qualitatively indicated by observed changes in the ${ }^{29} \mathrm{Si},{ }^{27} \mathrm{Al}$, and ${ }^{23} \mathrm{Na} \mathrm{NMR}$ spectra.

Another intriguing outcome of this approach can help to rationalize the seemingly dramatic effects of $\mathrm{Al}$ content on $\mathrm{Al}$ and $\mathrm{Si}$ coordination changes with pressure. Figure 9 shows, for $\mathrm{F}=0.6$, the percent volume decreases predicted separately from the observed $\mathrm{Si}$ and $\mathrm{Al}$ coordination changes, together with their sum; plots for larger values of $\mathrm{F}$ are similar, with all volume changes scaled down in proportion. For the three

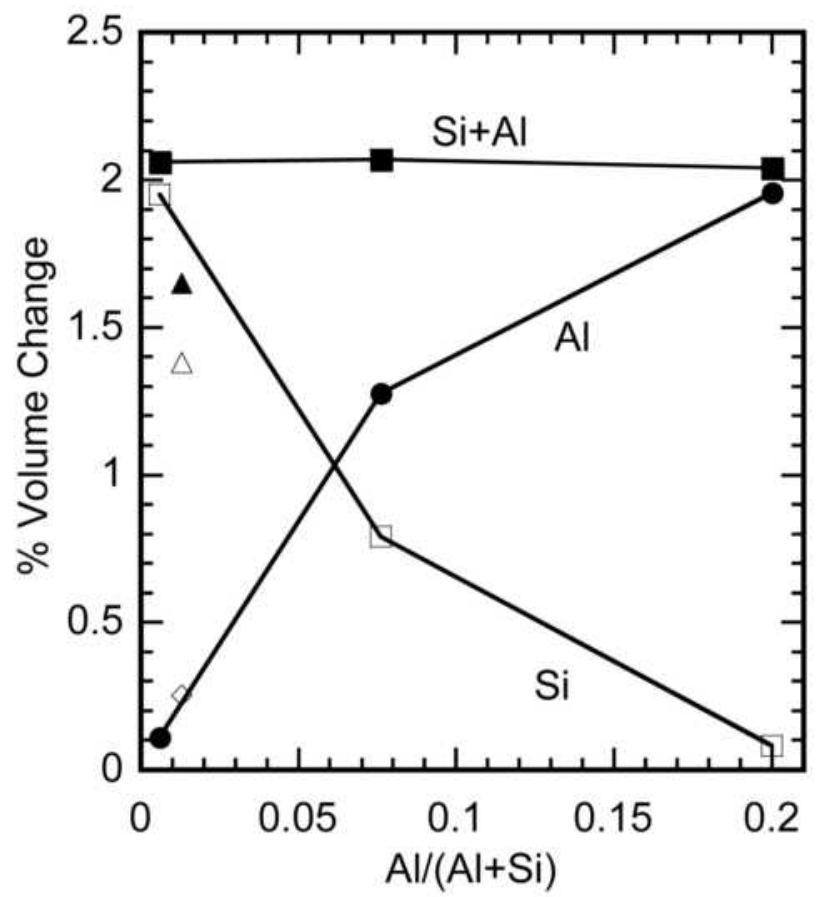

FIGURE 9. Percent volume changes estimated from observed $\mathrm{Al}$ and Si coordination increases using a simple model of partial molar volumes (see text) with $\mathrm{F}=0.6$. Lines are guides to the eye only. For the NS4 series (labeled curves), open squares represent the percentage of volume changes associated with $\mathrm{Si}$, solid circles with $\mathrm{Al}$, and solid squares $\mathrm{Si}+\mathrm{Al}$; for $\mathrm{NS} 3[\mathrm{Al} /(\mathrm{Al}+\mathrm{Si})=0.013$ only], the open triangle is for $\mathrm{Si}$, the open diamond for $\mathrm{Al}$, and the solid triangle for $\mathrm{Si}+\mathrm{Al}$. 
glasses in the NS4 series, the total predicted volume change is nearly constant, with a greater proportion resulting from $\mathrm{Al}$ as $\mathrm{Al} /(\mathrm{Al}+\mathrm{Si})$ increases. Rather remarkably, these glasses behave as if there is a constant, relatively small proportion (10-20\%) of the overall densification that is taken up by network cation coordination increases, regardless of composition. Because of the relative ease of formation of high-coordinated $\mathrm{Al}$ relative to $\mathrm{Si}$, the coordination number of $\mathrm{Al}$ is very high at low $\mathrm{Al}$ contents, but this contributes only a small part of the volume decrease, which in turn is taken up mostly by coordination increase of $\mathrm{Si}$; at higher $\mathrm{Al}$ contents, the same volume decrease can occur with little or no Si coordination change. The one available set of data for the NS3 series gives similar predicted volume changes, but probably somewhat reduced by the higher NBO content. Whether or not this trade-off among volume changes attributable to $\mathrm{Si}$ and $\mathrm{Al}$ coordination changes prevails over a wider compositional range, and how it relates to effects of other structural changes, will be important questions for future studies.

\section{ACKNOWLEDGMENTS}

We are grateful to Bob Jones for microprobe analyses, to NSF for funding under grants numbered EAR-0408410 (support for Kelsey and Stebbins) and OCE-0550216 (support for Mosenfelder and Asimow), and to J. Puglisi and C. Liu for access to the 18.8 T NMR spectrometer at the Stanford Magnetic Resonance Laboratory.

\section{REFERENCES CITED}

Allwardt, J.R., Schmidt, B.C., and Stebbins, J.F. (2004) Structural mechanisms of compression and decompression in high-pressure $\mathrm{K}_{2} \mathrm{Si}_{4} \mathrm{O}_{9}$ glasses: An investigation utilizing Raman and NMR spectroscopy of glasses and crystalline materials. Chemical Geology, 213, 137-151.

Allwardt, J.R., Poe, B.T., and Stebbins, J.F. (2005a) The effect of fictive temperature on Al-coordination in high-pressure ( $10 \mathrm{GPa}$ ) sodium aluminosilicate glasses. American Mineralogist, 90, 1453-1457.

Allwardt, J.R., Stebbins, J.F., Schmidt, B.C., Frost, D.J., Withers, A.C., and Hirschmann, M.M. (2005b) Aluminum coordination and density of high-pressure aluminosilicate glasses. American Mineralogist, 90, 1218-1222.

Allwardt, J.R., Stebbins, J.F., Schmidt, B.C., and Frost, D.J. (2005c) The effect of composition, compression, and decompression on the structure of high-pressure aluminosilicate glasses: An investigation utilizing ${ }^{17} \mathrm{O}$ and ${ }^{27} \mathrm{Al}$ NMR. In J. Chen, Y. Wang, T.S. Duffy, G. Shen, and L.F. Dobrzhinetskaya, Eds., Frontiers of High Pressure Research for Geophysical Applications, p. 211-240. Elsevier, Amsterdam.

Allwardt, J.R., Stebbins, J.F., Terasaki, H., Du, L.S., Frost, D.J., Withers, A.C., Hirschmann, M.M., Suzuki, A., and Ohtani, E. (2007) Effect of structural transitions on properties of high-pressure silicate melts: ${ }^{27} \mathrm{Al} \mathrm{NMR}$, glass densities, and melt viscosities. American Mineralogist, 92, 1093-1104.

Brow, R.K., Kirkpatrick, R.J., and Turner, G.L. (1993) Nature of alumina in phosphate glasses: II, Structure of sodium aluminophosphate glass. Journal of the American Ceramic Society, 76, 919-928.

Dickenson Jr., J.E., Scarfe, C.M., and McMillan, P. (1990) Physical properties and structures of $\mathrm{K}_{2} \mathrm{Si}_{4} \mathrm{O}_{9}$ melt quenched from pressures up to $2.4 \mathrm{GPa}$. Journal of Geophysical Research, 95, 15675-15681.

Donovan, J.J. and Tingle, T.N. (1996) An improved mean atomic number background correction for quantitative microanalysis. Journal of the Microscopy Society of America, 2, 1-7.

Doweidar, H. (1996) The density of alkali silicate glasses in relation to the microstructure. Journal of Non-Crystalline Solids, 194, 155-162.

(2001) Modeling of density structure relations in silicate glasses containing $\mathrm{Al}_{2} \mathrm{O}_{3}$. Physics and Chemistry of Glasses, $42,42-48$.

Dubinsky, E.V. and Stebbins, J.F. (2006) Quench rate and temperature effects on framework ordering in aluminosilicate melts. American Mineralogist, $91,753-761$.

Farber, D.L. and Williams, Q. (1996) An in situ Raman spectroscopic study of $\mathrm{Na}_{2} \mathrm{Si}_{2} \mathrm{O}_{5}$ at high pressures and temperatures: Structures of compressed liquids and glasses. American Mineralogist, 81, 273-283.

Kelsey, K.E., Stebbins, J.F., Du, L.S., and Hankins, B. (2007) Constraining ${ }^{17} \mathrm{O}$ and ${ }^{27} \mathrm{Al}$ NMR spectra of high-pressure crystals and glasses: New data for jadeite, pyrope, grossular, and mullite. American Mineralogist, 92, 210-216.

Kelsey, K.E., Stebbins, J.F., and Allwardt, J.R. (2008) Ca-Mg mixing in aluminosilicate glasses: An investigation using ${ }^{17} \mathrm{O}$ MAS and 3 QMAS and ${ }^{27} \mathrm{Al}$ MAS
NMR. Journal of Non-Crystalline Solids, 354, 4644-4653.

Kelsey, K.E., Stebbins, J.F., Singer, D.M., Brown Jr., G.E., Mosenfelder, J.L., and Asimow, P.D. (2009) Cation field strength effects on high pressure aluminosilicate glass structure: Multinuclear NMR and La XAFS results. Geochimica et Cosmochimica Acta, 73, 3914-3933.

Kirkpatrick, R.J. (1988) MAS NMR spectroscopy of minerals and glasses. In F.C. Hawthorne, Ed., Spectroscopic Methods in Mineralogy and Geology, 18, p. 341-403. Reviews in Mineralogy and Geochemistry, Mineralogical Society of America, Chantilly, Virginia.

Kushiro, I. (1976) Changes in viscosity and structure of melt of $\mathrm{NaAlSi}_{2} \mathrm{O}_{6}$ composition at high pressures. Geophysical Research Letters, 81, 6347-6350.

Kushiro, I. and Mysen, B.O. (2002) A possible effect of melt structure on the $\mathrm{Mg}-\mathrm{Fe}^{2+}$ partitioning between olivine and melt. Geochimica et Cosmochimica Acta, 66, 2267-2272.

Lange, R.A. (1997) A revised model for the density and thermal expansivity of $\mathrm{K}_{2} \mathrm{O}-\mathrm{Na}_{2} \mathrm{O}-\mathrm{CaO}-\mathrm{MgO}-\mathrm{Na}_{2} \mathrm{O}_{3}-\mathrm{SiO}_{2}$ liquids from 700 to $1900 \mathrm{~K}$ : Extension to crustal magmatic temperatures. Contributions to Mineralogy and Petrology, $130,1-11$.

Lee, S.K. (2004) Structure of silicate glasses and melts at high pressure: Quantum chemical calculations and solid-state NMR. Journal of Physical Chemistry B, $108,5889-5900$.

- (2005) Microscopic origins of macroscopic properties of silicate melts and glasses at ambient and high pressure: Implications for melt generation and dynamics. Geochimica et Cosmochimica Acta, 69, 3695-3710.

Lee, S.K. and Stebbins, J.F. (1999) The degree of aluminum avoidance in aluminosilicate glasses. American Mineralogist, 84, 937-945.

(2003) The distribution of sodium ions in aluminosilicate glasses: A high-field ${ }^{23} \mathrm{Na}$ MAS and 3QMAS NMR study. Geochimica et Cosmochimica Acta, 67, 1699-1709.

Lee, S.K., Fei, Y.W., Cody, G.D., and Mysen, B.O. (2003) Order and disorder in sodium-silicate glasses and melts at $10 \mathrm{GPa}$. Geophysical Research Letters, $30,1845-1848$

(2004) Nature of polymerization and properties of silicate melts and glasses at high pressure. Geochimica et Cosmochimica Acta, 68, 4189-4200.

(2006) The effect of $\mathrm{Na} / \mathrm{Si}$ on the structure of sodium silicate and aluminosilicate glasses quenched from melts at high pressure: A multi-nuclear $\left({ }^{27} \mathrm{Al},{ }^{23} \mathrm{Na},{ }^{17} \mathrm{O}\right) 1 \mathrm{D}$ and 2D solid-state NMR study. Chemical Geology, 229, $162-172$.

Li, D., Secco, R.A., Bancroft, G.M., and Fleet, M.E. (1995) Pressure induced coordination change of $\mathrm{Al}$ in silicate melts from $\mathrm{Al} K$ edge XANES of high pressure $\mathrm{NaAlSi}_{2} \mathrm{O}_{6}-\mathrm{NaAlSi}_{3} \mathrm{O}_{8}$ glasses. Geophysical Research Letters, 22, 3111-3114.

Lower, N.P., Brow, R.K., and Kurkjian, C.R. (2004) Inert failure strain studies of sodium silicate glass fibers. Journal of Non-Crystalline Solids, 349, 168-172.

MacKenzie, K. and Smith, M.E. (2002) Multinuclear Solid-State Nuclear Magnetic Resonance of Inorganic Materials, 6, 727 p. Pergamon, Amstersdam.

Mysen, B.O. and Richet, P. (2005) Silicate Glasses and Melts. Properties and Structure, 544 p. Elsevier, Amsterdam.

Mysen, B.O., Lucier, A., and Cody, G.D. (2003) The structural behavior of $\mathrm{Al}^{3+}$ in peralkaline melts and glasses in the system $\mathrm{Na}_{2} \mathrm{O}-\mathrm{Al}_{2} \mathrm{O}_{3}-\mathrm{SiO}_{2}$. American Mineralogist, 88, 1668-1678.

Nakashima, T., Maeda, K., and Nakao, Y. (2001) Glass for a substrate. U.S. Patent no. 6313052. U.S. Patent and Trademark Office, Alexandria, Virginia.

Neuville, D.R. and Mysen, B.O. (1996) Role of aluminum in the silicate network: In situ, high-temperature study of glasses and melts on the join $\mathrm{SiO}_{2}-\mathrm{NaAlO}_{2}$. Geochimica et Cosmochimica Acta, 60, 1727-1737.

Neuville, D.R., Cormier, L., and Massiot, D. (2006) Al coordination and speciation in calcium aluminosilicate glasses: Effects of composition determined by ${ }^{27} \mathrm{Al}$ MQ-MAS NMR and Raman spectroscopy. Chemical Geology, 229, 173-185.

Pinnow, D.A., Vanuitert, L.G., Rich, T.C., Ostermayer, F.W., and Grodkiewicz, W.H (1975) Investigation of soda aluminosilicate glass system for application to fiber optical-waveguides. Materials Research Bulletin, 10, 133-146.

Poe, B.T., Romano, C., Zotov, N., Cibin, F., and Marcelli, A. (2001) Compression mechanisms in aluminosilicate melts: Raman and XANES spectroscopy of glasses quenched from pressures up to $10 \mathrm{GPa}$. Chemical Geology, 174, 21-31.

Rigden, S.M., Ahrens, T.J., and Stolper, E.M. (1984) Densities of liquid silicates at high pressures. Science, 226, 1071-1074.

Scarfe, C.M., Mysen, B.O., and Virgo, D. (1987) Pressure dependence of the viscosity of silicate melts. In B.O. Mysen, Ed., Magmatic Processes: Physicochemical Principles, p. 59-67. Geochemical Society, University Park, Pennsylvania.

Schmidt, B.C., Riemer, T., Kohn, S.C., Behrens, H., and Dupree, R. (2000) Different water solubility mechanisms in hydrous glasses along the Qz-Ab Join: Evidence from NMR Spectroscopy. Geochimica et Cosmochimica Acta, 64, 513-526.

Sen, S. and Stebbins, J.F. (1994) Phase separation, clustering, and intermediate range order in $\mathrm{Li}_{2} \mathrm{Si}_{4} \mathrm{O}_{9}$ glass: a ${ }^{29} \mathrm{Si}$ MAS NMR spin-lattice relaxation study. Physical Review B, 50, 822-830. 
Stebbins, J.F. and McMillan, P. (1993) Compositional and temperature effects on 5 -coordinated silicon in ambient pressure silicate-glasses. Journal of NonCrystalline Solids, 160, 116-125.

Stebbins, J.F. and Poe, B.T. (1999) Pentacoordinate silicon in high-pressure crystalline and glassy phases of calcium disilicate $\left(\mathrm{CaSi}_{2} \mathrm{O}_{5}\right)$. Geophysical Research Letters, 26, 2521-2523.

Stebbins, J.F., Dubinsky, E.V., Kanehashi, K., and Kelsey, K.E. (2008) Temperature effects on non-bridging oxygen and aluminum coordination number in calcium aluminosilicate glasses and melts. Geochimica et Cosmochimica Acta, 72, 910-925.

Stolper, E.M., Walker, D., Hager, B.H., and Hays, J.F. (1981) Melt segregation from partially molten source regions: The importance of melt density and source regions' size. Journal of Geophysical Research, 86, 6261-6271.

Toplis, M.J., Dingwell, D.B., Hess, K.U., and Lenci, T. (1997) Viscosity, fragility, and configurational entropy of melts along the join $\mathrm{SiO}_{2}-\mathrm{NaAlSiO}_{4}$. American Mineralogist, 82, 979-990.

Webb, S.L. and Dingwell, D.B. (1995) Viscoelasticity. In J.F. Stebbins, P.F. McMillan, and D.B. Dingwell, Eds., Structure, Dynamics, and Properties of Silicate Melts, 32, p. 191-246. Reviews in Mineralogy and Geochemistry, Mineralogical Society of America, Chantilly, Virginia.

Wolf, G.H. and McMillan, P.F. (1995) Pressure effects on silicate melt structure and properties. In J.F. Stebbins, P.F. McMillan, and D.B. Dingwell, Eds., Structure, Dynamics, and Properties of Silicate Melts, 32, p. 506-561. Reviews in Mineralogy and Geochemistry, Mineralogical Society of America, Chantilly, Virginia.

Wolf, G.H., Durben, D.J., and McMillan, P.F. (1990) High-pressure spectroscopic study of sodium tetrasilicate $\left(\mathrm{Na}_{2} \mathrm{Si}_{4} \mathrm{O}_{9}\right)$ glass. Journal of Physical Chemistry, 93, 2280-2288.

Xue, X. and Stebbins, J.F. (1993) ${ }^{23}$ Na NMR chemical shifts and local Na coordination environments in silicate crystals, melts, and glasses. Physics and Chemistry of Minerals, 20, 297-307.

Xue, X., Stebbins, J.F., Kanzaki, M., and Trønnes, R.G. (1989) Silicon coordination and speciation changes in silicate liquids at high pressures. Science, $245,962-964$.

Xue, X., Stebbins, J.F., Kanzaki, M., McMillan, P.F., and Poe, B. (1991) Pressure induced silicon coordination and tetrahedral structural changes in alkali oxidesilica melts up to $12 \mathrm{GPa}$ : NMR, Raman, and infrared spectroscopy. American Mineralogist, 76, 8-26.

Xue, X., Stebbins, J.F., and Kanzaki, M. (1994) Correlations between ${ }^{17} \mathrm{O}$ NMR parameters and local structure around oxygen in high-pressure silicates: Implications for the structure of silicate melts at high pressure. American Mineralogist, 79, 31-42.

Yarger, J.L., Smith, K.H., Nieman, J., Diefenbacher, J., Wolf, G.H., Poe, B.T., and McMillan, P.F. (1995) Al coordination changes in high-pressure aluminosilicate liquids. Science, 270, 1964-1967.

MANUSCRIPT RECEIVED DECEMBER 19, 2008

MANUSCRIPT ACCEPTED APRIL 24, 2009

MANUSCRIPT HANDLED BY GRANT HENDERSON 